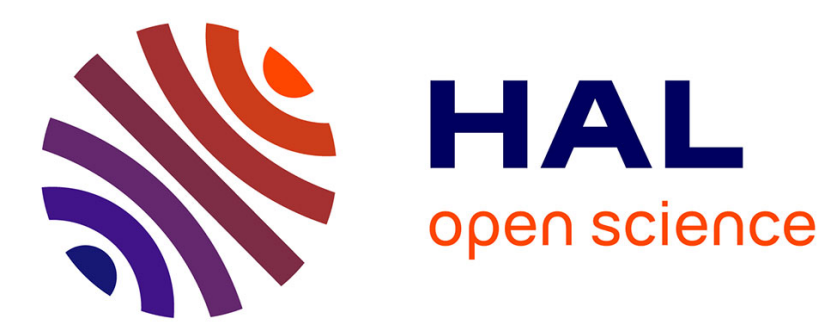

\title{
Patterns of litterfall and nutrient return at different altitudes in evergreen hardwood forests of Central Taiwan
}

$\mathrm{Lu}$, Liu

\section{- To cite this version:}

Lu, Liu. Patterns of litterfall and nutrient return at different altitudes in evergreen hardwood forests of Central Taiwan. Annals of Forest Science, 2012, 69 (8), pp.877-886. 10.1007/s13595-012-0213-4 . hal-00930862

\section{HAL Id: hal-00930862 \\ https://hal.science/hal-00930862}

Submitted on 1 Jan 2012

HAL is a multi-disciplinary open access archive for the deposit and dissemination of scientific research documents, whether they are published or not. The documents may come from teaching and research institutions in France or abroad, or from public or private research centers.
L'archive ouverte pluridisciplinaire HAL, est destinée au dépôt et à la diffusion de documents scientifiques de niveau recherche, publiés ou non, émanant des établissements d'enseignement et de recherche français ou étrangers, des laboratoires publics ou privés. 


\title{
Patterns of litterfall and nutrient return at different altitudes in evergreen hardwood forests of Central Taiwan
}

\author{
Shu-Wei Lu $\cdot$ Chiung-Pin Liu
}

Received: 9 November 2011 / Accepted: 13 April 2012 /Published online: 8 May 2012

(C) INRA / Springer-Verlag France 2012

\begin{abstract}
- Background This study was designed to evaluate the internal nutrient cycling of litterfall in different elevation subtropical forests of Central Taiwan.

- Methods The litterfall of evergreen hardwoods at three elevations, specifically Mt. Peitungyen (2,078 m), Hui-Sun experimental forest (HSEF) $(1,066 \mathrm{~m})$, and Lienhauchi $(782 \mathrm{~m})$ in central Taiwan, was collected monthly using traps and sorted into leaves, twigs, reproductive litter, and miscellaneous material. In addition, the litter on the forest floor was collected trimonthly. All the samples were weighed and measured for $\mathrm{C}, \mathrm{N}, \mathrm{P}, \mathrm{K}, \mathrm{Ca}$, and $\mathrm{Mg}$ concentrations and fluxes from March 2009 to February 2010.

- Results The annual litterfall productions were 6.58, 8.24, and $9.17 \mathrm{Mg} \mathrm{ha}^{-1}$ year $^{-1}$ at Mt. Peitungyen, HSEF, and Lienhauchi, respectively. At more than $60 \%$, leaves were the main component of the total litterfall. There was smallest decomposition constant (0.487) at Mt. Peitungyen. The nutrient fluxes increased as elevation decreased. The litterfall correlated positively with rainfall at Lienhauchi, with temperature at HSEF, and with temperature and rainfall at Mt. Peitungyen.

- Conclusion The annual litterfall decreased with an increase in elevation. The turnover rate was faster at HSEF than at Mt. Peitungyen. Thus, the forest managers should
\end{abstract}

\section{Handling Editor: Gilbert Aussenac}

Contribution of the co-authors Chiung-Pin Liu designed the study, performed research, analyzed data, and wrote the paper. Shu-Wei Lu performed the experiment and running the data analysis.

S.-W. Lu • C.-P. Liu $(\bowtie)$

Department of Forestry, National Chung Hsing University,

250 Kuo-Kuang Road,

Taichung 40227, Taiwan

e-mail: cpliu@nchu.edu.tw pay more attention to understand and monitor plant community responses to global warming and nutrient loss.

Keywords Elevation $\cdot$ Litterfall $\cdot$ Evergreen hardwood forest $\cdot$ Nutrient $\cdot$ Decomposition constant

\section{Introduction}

Litterfall nutrient condition affects the nutrient cycling from canopy to soil and could discover species ecological niche (recruitment or outcompete) in the forest (Staelens et al. 2011). The carbon and nitrogen level ratio of leaf litterfall was a fine mirror of $\mathrm{C}$ and $\mathrm{N}$ content of forest floor and decomposition constant of forest floor $\mathrm{C}$ and $\mathrm{N}$ (Vesterdal et al. 2008). Forest floor $\mathrm{C} / \mathrm{N}$ ratio might be predicated the decomposition process (Garten and Hanson 2006). C level, $\mathrm{C}$ content, and organic matter accumulation of forest floor increased with elevation (Horng et al. 2003; Yen and Shiang 2007). Moreover, the accumulation of litter may affect the environment and plant community structure and ecosystem process (Facelli and Pickett 1991; Tripathi et al. 2006).

Litterfall production can be related to topographic position (Aceñolaza et al. 2010), elevation (Röderstein et al. 2005), vegetation composition (Staelens et al. 2011), and geological substrates (Kitayama and Aiba 2002). Litterfall in different forests around the world has been reported as being strongly seasonal and driven by air temperature and rainfall patterns (Tripathi et al. 2006).

Elevation is a comprehensive factor related to temperature, rainfall, nitrogen deposition, and soil type that affects the storage and turnover of carbon (Garten and Hanson 2006). In recent years, meta-analyses have explored the effects of climate (temperature and rainfall) on litterfall (Berg and Meentemeyer 2001; Liu et al. 2004). Temperature 
and rainfall were shown to predict the litterfall production of bored leaves and control nearly half of the variation (Brown and Lugo 1982; Liu et al. 2004). Leaf litterfall nutrient level would show the nutrient resorption proficiency, and they reflect the site quality (Killingbeck 1996) and nutrient conservation (Killingbeck and Whitford 2001). Oleksyn et al. (2003) considered that northerly populations (colder temperature) had higher resorption proficiency than the lower latitude populations. $\mathrm{N}$ concentration of leaf litterfall had significant relationship with temperature and rainfall (Liu et al. 2006).

Many studies of litterfall, litter decomposition, and nutrient dynamics have been concerned with elevation (Reiners and Lang 1987; Pendry and Proctor 1996; Kitayama and Aiba 2002; Röderstein et al. 2005), but there was little information available in subtropical forests (e.g., Taiwan). Therefore, the objective of this study was to assess the effects of elevation factors (temperature and rainfall) on litterfall and the nutrient return of evergreen hardwoods at different elevations in central Taiwan. In this study, two questions were addressed: (1) What were the differences of litterfall on nutrient return along different elevation forests, and (2) did the differences correlate with temperature and rainfall? To answer these questions, we compared the litterfall (1) production, (2) components, (3) nutrient concentration and fluxes, (4) litter accumulation on the forest floor, and (5) the decomposition constant from evergreen hardwoods along these three different elevations.

\section{Materials and methods}

\subsection{Study sites}

This study was performed on evergreen hardwoods from three elevations ranging from 782 to $2,098 \mathrm{~m}$ in central Taiwan (Table 1). Mt. Peitungyen ( $24^{\circ} 04^{\prime} 24^{\prime \prime}$ N, $121^{\circ} 07^{\prime} 42^{\prime \prime}$ E; $2,098 \mathrm{~m}$ a.s.l.) was located in Renai Township, Nantou County. The leaf area index (LAI) was 1.27. The meteorological data (Fig. 1) showed that the annual precipitation was $2,800 \mathrm{~mm}$ and that the mean temperatures in January, July, and 1-year average were $6.5,16.9$, and $12.3^{\circ} \mathrm{C}$, respectively. Hui-Sun experimental forest (HSEF) $\left(24^{\circ} 04^{\prime} 31^{\prime \prime} \mathrm{N}, 121^{\circ} 02^{\prime}\right.$ $05^{\prime \prime} \mathrm{E} ; 1,066 \mathrm{~m}$ a.s.1.) is located in the Guandaushi watershed, Nantou County. The LAI was 1.81 . The annual precipitation was $3,041.1 \mathrm{~mm}$, and the mean temperatures in January, July, and 1-year average were $12.8,24.3$, and $19.4^{\circ} \mathrm{C}$, respectively. Lienhauchi was located in the Lienhauchi no. 5 watershed (23 ${ }^{\circ} 55^{\prime} 51^{\prime \prime} \mathrm{N}, 120^{\circ} 53^{\prime} 34^{\prime \prime}$ E; $782 \mathrm{~m}$ a.s.1.), Taiwan Forestry Research Institute, Nantou County. The LAI was 2.02. The annual precipitation was $2,132.5 \mathrm{~mm}$, and the mean temperatures in January, July, and one-year average were 14.6, 24.6, and $20.3^{\circ} \mathrm{C}$, respectively.

The dominant tree families were Fagaceae, Lauraceae, and Theaceae at Mt. Peitungyen and HSEF; their importance value indexes (IVIs) were 22.92, 21.81, and 9.99 at Mt. Peitungyen where there was montane evergreen broad-leaved forest formation, and then IVIs were $14.05,22.67$, and 5.11 at HSEF where there was lower montane evergreen broad-leaved forest. The dominant tree families were Lauraceae, Fagaceae, and Araliaceae at Lienhauchi where there was lower montane-lowland secondary broad-leaved forest, and their IVIs were 21.64, 16.06, and 4.58 (Chiou et al. 2009).

\subsection{Litterfall and litter collection}

The litterfall was collected monthly from March 2009 to February 2010 in the three evergreen hardwood forests using traps. These traps were nylon mesh $(1 \times 1 \mathrm{~mm})$ net and were set $45 \mathrm{~cm}$ above the forest floor. Nine litter traps were set randomly at each site. The litterfall samples were brought to the laboratory and sorted into four portions: leaves (bud, stipule), reproductive material (e.g., flowers, fruits, and seeds), twigs (small branches with diameter $<2.0 \mathrm{~cm}$ and bark), and other material (e.g., unrecognizable plant debris $<2 \mathrm{~mm}$ in size, epiphytes, insect bodies, and feces). The sorted components were oven-dried at $65^{\circ} \mathrm{C}$ for

Table 1 Sites characteristic of nature hardwoods among three elevations in central Taiwan

\begin{tabular}{|c|c|c|c|c|c|c|c|}
\hline Sites & Location & $\begin{array}{l}\text { Elevation } \\
\text { (m a.s.1.) }\end{array}$ & $\begin{array}{l}\text { Mean air } \\
\text { temperature }\left({ }^{\circ} \mathrm{C}\right)\end{array}$ & $\begin{array}{l}\text { Rainfall } \\
\left(\mathrm{mm}_{\text {year }}{ }^{-1}\right)\end{array}$ & $\begin{array}{l}\text { Mean air } \\
\text { humidity (\%) }\end{array}$ & Area (ha) & $\begin{array}{l}\text { Leaf area } \\
\text { index }{ }^{\mathrm{a}}\left(\mathrm{m}^{2} \mathrm{~m}^{-2}\right)\end{array}$ \\
\hline Mt Peitungyen & $\begin{array}{l}24^{\circ} 04^{\prime} 24^{\prime \prime} \mathrm{N} \\
121^{\circ} 07^{\prime} 42^{\prime \prime} \mathrm{E}\end{array}$ & 2,098 & 12.3 & $2,802.5$ & 91.2 & 2,373 & $1.27^{\mathrm{z}, \mathrm{b}}$ \\
\hline HSEF & $\begin{array}{l}24^{\circ} 04^{\prime} 31^{\prime \prime} \mathrm{N} \\
121^{\circ} 02^{\prime} 05^{\prime \prime} \mathrm{E}\end{array}$ & 1,066 & 19.4 & $3,041.1$ & 84.8 & 210 & $1.81^{\mathrm{y}}$ \\
\hline Lienhauchi & $\begin{array}{l}23^{\circ} 55^{\prime} 51^{\prime \prime} \mathrm{N} \\
120^{\circ} 53^{\prime} 34^{\prime \prime} \mathrm{E}\end{array}$ & 782 & 20.3 & $2,132.5$ & 96.1 & 461 & $2.02^{\mathrm{x}}$ \\
\hline
\end{tabular}

HSEF Hui-Sun Experiment Forest, Nationl Chung Hsing University

${ }^{a}$ We measured leaf area index in March, 2010

$\mathrm{b}$ The means of leaf area index with the same letter $(\mathrm{x}, \mathrm{y}, \mathrm{z})$ do not differ significantly at $\alpha=0.05$ 
Fig. 1 Variability of monthly rainfull $(\mathrm{mm})$ and temperature $\left({ }^{\circ} \mathrm{C}\right)$ amount at three evergreen hardwoods in central Taiwan during March 2009 to February 2010

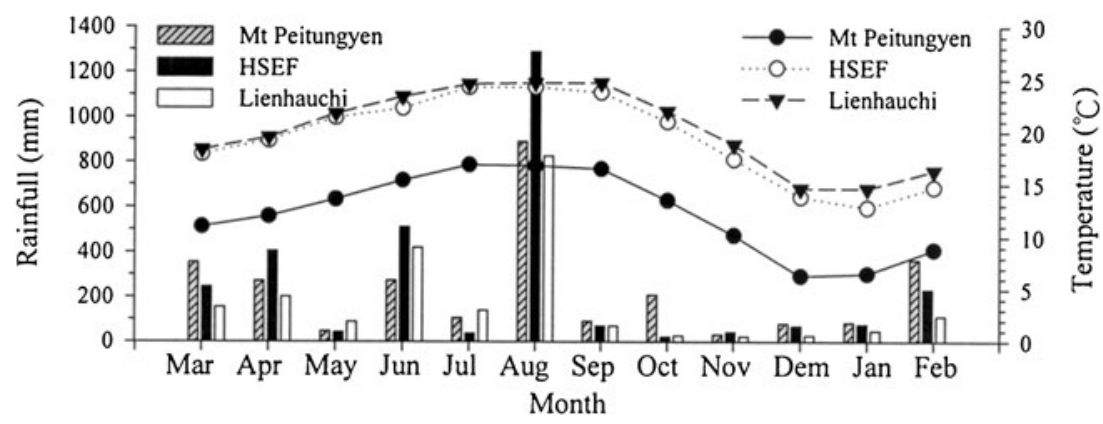

7 days to constant weight, weighed, and milled for chemical analysis.

The fine litter on the forest floor was sampled using a $625-\mathrm{cm}^{2}$ wooden frame once every three months from March to December, 2009. Three to six randomly distributed replicate samples at each elevation were taken. These samples were oven-dried at $65^{\circ} \mathrm{C}$ for 7 days and weighed.

\subsection{Chemical analysis}

Samples for analysis were ground, homogenized, and passed through a $0.2-\mathrm{mm}$ sieve, then digested by triacid digestion (perchloric, nitric, and sulfuric, 1:5:1). The $\mathrm{P}, \mathrm{K}, \mathrm{Ca}$, and $\mathrm{Mg}$ concentrations were measured using inductively coupled plasma-atomic emission spectrometry (Leeman Labs, USA). The total $\mathrm{C}$ and $\mathrm{N}$ contents were analyzed via dry combustion using an elemental analyzer (CHNOS Elemental Analyzer, Vario EL, Germany).

\subsection{Data processing and statistical analysis}

Mean values were calculated for each category and each sampling date at each site. Nutrient content was calculated by mean concentration (\%) of each element multiplied by the mean mass of each litterfall components. The ratios of $\mathrm{C}$ to $\mathrm{N}$ were calculated by $\mathrm{C}$ concentration in litterfall divided by $\mathrm{N}$ concentration. The nutrient content $\left(\mathrm{kg} \mathrm{ha}^{-1}\right)$ of each litterfall component per month and/or per year was estimated by mean concentrations (\%) of each element in each litterfall components multiplied by the mean mass of the litterfall component $\left(\mathrm{Mg} \mathrm{ha}^{-1}\right)$ per month and/or per year for each site.

The effects of elevation on mass, nutrient concentrations, the fluxes of litterfall components, and their accumulation in the litter were analyzed using Duncan's new multiple range tests. The relations between the different litterfall components and the temperature or precipitation were analyzed using Pearson's correlations. All statistical analyses were performed using the procedure generalized linear model in the SAS System v. 9.1.3 for Windows, and the accepted level of significance was $p<0.05$. Moreover, we estimated the decomposition constant $(k)$ of the litter using the mass balance method (Olson 1963). The mass loss over time was fitted to a simple negative exponential model:

$$
\ln \left(x_{1} / x_{0}\right)=-k t
$$

where $x_{0}$ is the original mass of the litter, $x_{t}$ is the amount of litter remaining after time $t, t$ is the time (year), and $k$ is the decomposition rate $\left(\right.$ year $\left.^{-1}\right)$.

\section{Results}

\subsection{Litterfall along different elevation sites}

The total litterfall ranged from 6.58 to $9.17 \mathrm{Mg} \mathrm{ha}^{-1}$ year $^{-1}$ along the three evergreen hardwood forests in central Taiwan during the period from March 2009 to February 2010. The litterfall at the lowest site was significantly higher than at the highest site. The annual litterfall decreased with elevation (Table 2). The leaf litterfall at the lowest site was significantly higher than that at the highest site. On the contrary, the reproductive litter at the lowest site was lower than at the highest site. Twigs and other materials were not significant among the three different elevation forests.

The correlation coefficient between the components of litterfall and the climate variables (rainfall and temperature) during the 1-year period indicated (Table 3) that the leaf litterfall was positively correlated with temperature at Mt. Peitungyen and positively correlated with rainfall at Lienhauchi. The twig litterfall correlated positively with rainfall at Mt. Peitungyen and Lienhauchi. Other materials correlated positively with temperature at all three elevations. The total litterfall correlated positively with rainfall at Lienhauchi, with temperature at HSEF, and with temperature and rainfall at Mt. Peitungyen.

\subsubsection{Spatial and temporal variation in litterfall}

The variation in the monthly litterfall among the three evergreen hardwood forests is shown in Fig. 2. In terms of leaf litterfall, there were two peaks at each site during the year, in May and August at Mt. Peitungyen and Lienhauchi and in May and July at HSEF. The lowest production was in 
Table 2 The litterfall $\left(\mathrm{Mg} \mathrm{ha}^{-1}\right.$ year $\left.^{-1}\right)$ among components and elevations in central Taiwan during March 2009 to February 2010 (mean \pm standard deviation)

\begin{tabular}{|c|c|c|c|c|c|c|}
\hline \multirow[t]{2}{*}{ Fraction/site } & \multicolumn{2}{|l|}{ Mt Peitungyen } & \multicolumn{2}{|l|}{ HSEF } & \multicolumn{2}{|l|}{ Lienhauchi } \\
\hline & $\mathrm{Mg} \mathrm{ha}^{-1}$ year $^{-1}$ & $\%$ & $\mathrm{Mg} \mathrm{ha}^{-1}$ year $^{-1}$ & $\%$ & $\mathrm{Mg} \mathrm{ha}^{-1}$ year $^{-1}$ & $\%$ \\
\hline Leaves & $4.01 \pm 0.63^{\mathrm{y}, \mathrm{a}}$ & 61 & $5.37 \pm 1.00^{\mathrm{x}, \mathrm{a}}$ & 65 & $6.10 \pm 2.09^{\mathrm{x}, \mathrm{a}}$ & 67 \\
\hline Twigs & $1.20 \pm 0.83^{\mathrm{x}, \mathrm{b}}$ & 18 & $1.55 \pm 0.64^{\mathrm{x}, \mathrm{b}}$ & 19 & $2.06 \pm 1.12^{\mathrm{x}, \mathrm{b}}$ & 22 \\
\hline Reproduction & $1.032 \pm 0.557^{\mathrm{x}, \mathrm{b}}$ & 16 & $0.788 \pm 0.457^{\mathrm{xy}, \mathrm{c}}$ & 10 & $0.534 \pm 0.340^{\mathrm{y}, \mathrm{c}}$ & 6 \\
\hline Other material & $0.348 \pm 0.074^{\mathrm{x}, \mathrm{c}}$ & 5 & $0.531 \pm 0.291^{\mathrm{x}, \mathrm{c}}$ & 6 & $0.479 \pm 0.263^{\mathrm{x}, \mathrm{c}}$ & 5 \\
\hline Total & $6.58 \pm 1.51^{\mathrm{y}}$ & & $8.24 \pm 1.13^{\mathrm{xy}}$ & & $9.17 \pm 3.51^{\mathrm{x}}$ & \\
\hline
\end{tabular}

Different letters indicate significant difference between components within a column and elevations within a row at $p<0.05$

January at each site. The ratios of the highest to the lowest production were 10.5, 4.8, and 5.6 at Mt. Peitungyen, HSEF, and Lienhauchi, respectively. The obvious variation of the monthly litterfall in twig production is shown in Fig. 2b. At Mt. Peitungyen and Lienhauchi, the highest peaks were found in August. At HSEF, there were two peaks, in July and October. The lowest production was in September at Mt. Peitungyen and HSEF and in January at Lienhauchi. The ratios of the highest to the lowest production were 130.4, 20.4, and 34.0 at Mt. Peitungyen, HSEF, and Lienhauchi, respectively. There was significant variation at Mt. Peitungyen.

The variation of monthly reproduction is shown in Fig. 2c. There were three peaks, in August, June, and December, at Mt. Peitungyen, and the lowest production was found in September. There were two peaks, in July and April, at HSEF with the lowest production in January. The highest production was in June, and the lowest was in January at Lienhauchi. We identified the reproductive material as Schima superba capsule in June, flowers in August, and Michelia compressa follicles in December at Mt. Peitungyen. At HSEF, we found Helicia formosana fruit and Castanopsis kawakamii staminate flowers in April and Litsea acuminata staminate flowers in July. At Lienhauchi, the composition of the reproductive litter included pods of
Mucuna macrocarpa in May and Engelhardtia roxburghiana staminate flowers in catkins in June.

The monthly variation of the other material is displayed in 2(d). There was a clear peak in August at Mt. Peitungyen, and during May to August, the fluctuant range of mass was $36.0-84.2 \mathrm{~kg} \mathrm{ha}^{-1}$. The range was 12.4-23.0 kg ha ${ }^{-1}$ in the other months. At HSEF, the highest mass was found in July and the lowest mass was found in December. At Lienhauchi, the first peak was in June, the second peak was in August and the lowest peak was in December.

\subsection{Fractions of litterfall}

The different components of litterfall production at the three evergreen hardwood forests are shown in Table 2. The leaf litterfall was significantly higher than any other fractions. This portion accounted for $61-67 \%$ of the total litterfall. In relation to the elevation, Lienhauchi and HSEF had significantly higher leaf portions than Mt. Peitungyen, but the reproductive litter at Mt. Peitungyen was significantly higher than at Lienhauchi. The second largest portion was twigs, which accounted for $18-22 \%$ of the total litterfall. The reproductive litter made up $6-16 \%$ of the total litterfall. The smallest portion was other material, accounting for
Table 3 Correlation coefficients between litterfall components of evergreen hardwoods and air temperature and rainfall at three elevations in central Taiwan

${ }^{*} p<0.05 ; * * p<0.01$

$* * * p<0.001$

\begin{tabular}{llllll}
\hline & Leaves & Twigs & Reproduction & Other & Total \\
\hline Mt Peitungyen & & & & \\
Rainfall $(\mathrm{mm})$ & 0.299 & $0.895^{* * *}$ & 0.540 & $0.678^{*}$ & $0.629^{*}$ \\
Temperature $\left({ }^{\circ} \mathrm{C}\right)$ & $0.654^{*}$ & 0.370 & 0.194 & $0.628^{*}$ & $0.591^{*}$ \\
HSEF & & & & 0.043 & -0.022 \\
Rainfall $(\mathrm{mm})$ & 0.003 & -0.060 & -0.010 & $0.663^{*}$ & $0.659^{*}$ \\
Temperature $\left({ }^{\circ} \mathrm{C}\right)$ & 0.561 & 0.390 & 0.465 & & $0.830^{* * *}$ \\
Lienhauchi & & & & $0.887^{* * *}$ \\
Rainfall $(\mathrm{mm})$ & $0.594^{*}$ & $0.885^{* *}$ & 0.534 & $0.752^{* *}$ & 0.558 \\
Temperature $\left({ }^{\circ} \mathrm{C}\right)$ & 0.522 & 0.433 & 0.464 & & \\
\hline
\end{tabular}


Fig. 2 Variability of monthly litterfall fraction (mean \pm SE). a Leaves. b Twigs. c

Reproduction. d Other. e Total amount at three evergreen hardwoods in central Taiwan during March 2009 to February 2010
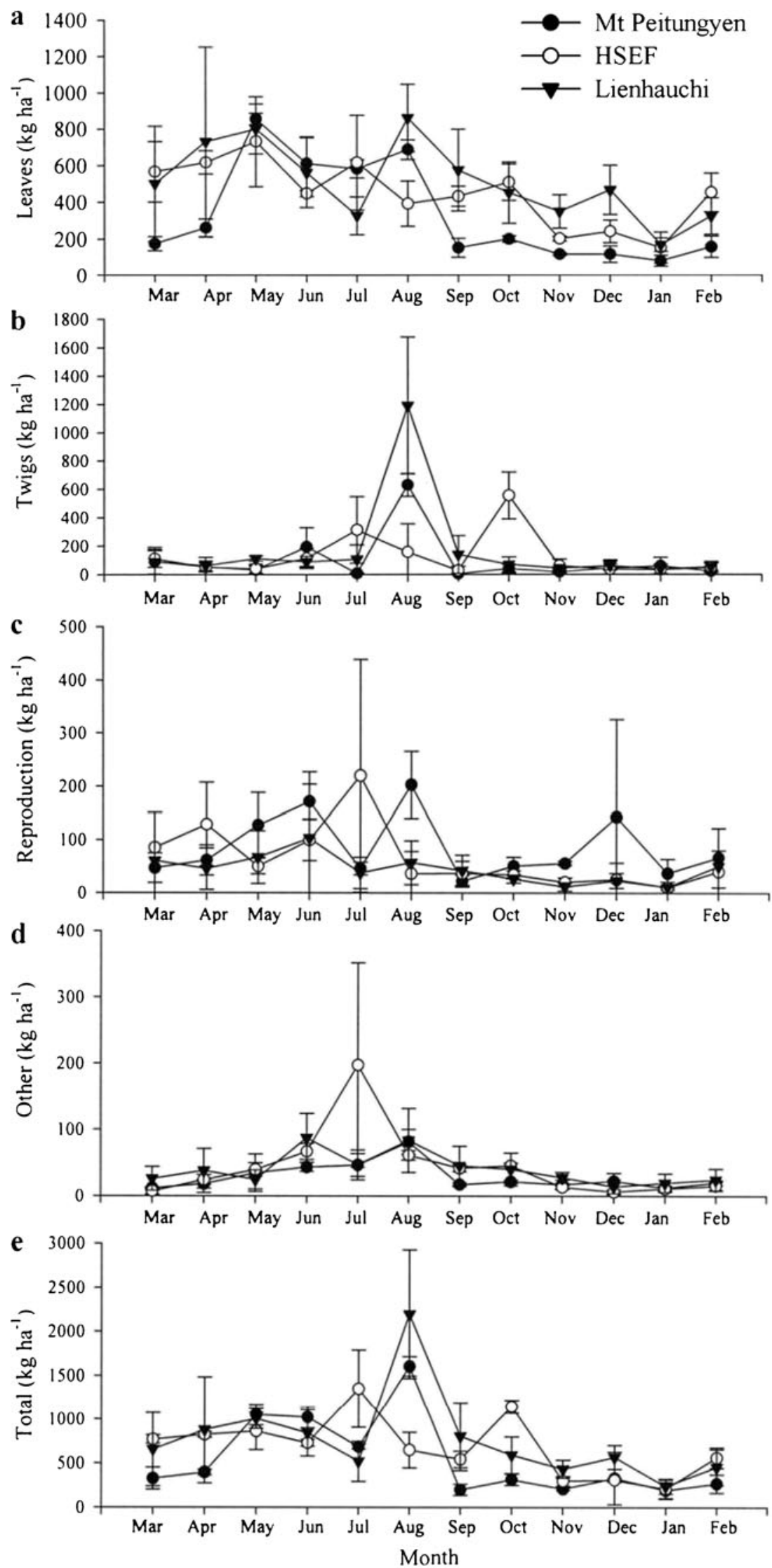
approximately $5-6 \%$ of the total litterfall, and there were no significant differences among the elevations.

\subsection{Litterfall nutrient concentrations and fluxes}

The $\mathrm{N}$ concentration in the leaf litterfall at Lienhauchi was significantly higher than at HSEF, and the K concentration in the leaf litterfall was the highest at Lienhauchi (Table 4). The $\mathrm{C}, \mathrm{Ca}$, and $\mathrm{Mg}$ concentrations in the twig litter showed no significant differences among the elevation sites. At Lienhauchi, the $\mathrm{N}$ and $\mathrm{K}$ concentration in the branch litter was the highest among the different elevations. The litterfall $\mathrm{P}$ concentration of leaves and twigs at Mt. Peitungyen was higher than at HSEF, but no significance at Lienhauchi The carbon concentration of the reproductive litter at Mt. Peitungyen was higher than at HSEF but showed no significant difference with Lienhauchi. The $\mathrm{K}$ concentration of the reproductive litter at Lienhauchi was higher than at Mt. Peitungyen, but the N, P, $\mathrm{Ca}$, and $\mathrm{Mg}$ concentrations were not significantly different among the elevation sites. The nutrient concentrations in the other material of the litterfall were not significantly different among the elevation sites, except that the $\mathrm{K}$ at Lienhauchi was higher than at HSEF.

The different portions of the litterfall had different nutrient content. The $\mathrm{N}$ content in the other material was the highest, followed by the reproductive litter and then the leaf and the twig litterfall. The $\mathrm{Ca}$ concentration was the highest in the branches. The $\mathrm{P}$ concentration of the other material and the reproductive litter was higher than that of the leaves and twigs. The $\mathrm{K}$ concentration was highest in the reproductive litter and lowest in the twigs.
The nutrient fluxes of $\mathrm{C}, \mathrm{N}, \mathrm{P}, \mathrm{K}, \mathrm{Ca}$, and $\mathrm{Mg}$ tended to be higher at Lienhauchi than at HSEF and Mt. Peitungyen (Table 5). The leaf litterfall was the most important pathway for nutrient return at each site. The leaves contributed more than $60 \%$ of the C, N, K, Ca and Mg fluxes, except that the $\mathrm{N}$ and $\mathrm{Ca}$ fluxes were slightly low at Mt. Peitungyen. The $\mathrm{P}$ flux in the reproductive litter contributed $27 \%$ of the total litterfall, which was more than half the leaves contribution at Mt. Peitungyen. Overall, the N and K fluxes at Lienhauchi were significant higher than at Mt. Peitungyen.

\subsection{Litter accumulation and turnover rate}

The mass of litter among the elevation sites showed no significant differences. The carbon concentration was significantly higher at Mt. Peitungyen than at Lienhauchi. The K concentration was significantly higher at Lienhauchi than at HSEF and Mt. Peitungyen (Table 6). The $\mathrm{C} / \mathrm{N}$ in the litter layer was higher at Mt. Peitungyen and at HSEF than at Lienhauchi.

The decomposition constants were $0.487,0.777$ and 0.764 at Mt. Peitungyen, HSEF, and Lienhauchi, respectively. The litterfall decomposition constants showed that faster rate was at HSEF and Lienhauchi, then slower was at Mt Peitungyen.

\section{Discussion}

\subsection{Litterfall mass along different elevation sites}

The annual litterfall productions at the three sites in central Taiwan were within the range of tropical broadleaf evergreen
Table 4 Nutrient concentration (\%) of litterfall during March 2009 to February 2010 at three elevations in central Taiwan

Significant differences among elevations $(p<0.05)$ were indicated by letters

\begin{tabular}{|c|c|c|c|c|c|c|}
\hline \multirow[t]{2}{*}{ Parameter } & \multicolumn{6}{|c|}{ Nutrient concentration (\%) } \\
\hline & $\mathrm{C}$ & $\mathrm{N}$ & $\mathrm{P}$ & $\mathrm{K}$ & $\mathrm{Ca}$ & $\mathrm{Mg}$ \\
\hline \multicolumn{7}{|l|}{ Leaves } \\
\hline Mt Peitungyen & $49.8^{\mathrm{a}}$ & $1.51^{\mathrm{ab}}$ & $0.0473^{\mathrm{a}}$ & $0.385^{\mathrm{b}}$ & $0.548^{\mathrm{a}}$ & $0.182^{\mathrm{a}}$ \\
\hline HSEF & $49.5^{\mathrm{a}}$ & $1.37^{\mathrm{b}}$ & $0.0370^{\mathrm{b}}$ & $0.309^{\mathrm{c}}$ & $0.501^{\mathrm{ab}}$ & $0.154^{\mathrm{b}}$ \\
\hline Lienhauchi & $50.5^{\mathrm{a}}$ & $1.66^{\mathrm{a}}$ & $0.0482^{\mathrm{a}}$ & $0.465^{\mathrm{a}}$ & $0.453^{\mathrm{b}}$ & $0.155^{\mathrm{b}}$ \\
\hline \multicolumn{7}{|l|}{ Twigs } \\
\hline Mt Peitungyen & $48.8^{\mathrm{a}}$ & $1.25^{\mathrm{b}}$ & $0.0530^{\mathrm{a}}$ & $0.282^{\mathrm{ab}}$ & $0.643^{\mathrm{a}}$ & $0.185^{\mathrm{a}}$ \\
\hline HSEF & $48.9^{\mathrm{a}}$ & $1.07^{\mathrm{b}}$ & $0.0364^{\mathrm{b}}$ & $0.198^{\mathrm{b}}$ & $0.645^{\mathrm{a}}$ & $0.154^{\mathrm{a}}$ \\
\hline Lienhauchi & $48.6^{\mathrm{a}}$ & $1.54^{\mathrm{a}}$ & $0.0404^{\mathrm{ab}}$ & $0.371^{\mathrm{a}}$ & $0.608^{\mathrm{a}}$ & $0.150^{\mathrm{a}}$ \\
\hline \multicolumn{7}{|l|}{ Reproduction } \\
\hline Mt Peitungyen & $49.9^{\mathrm{a}}$ & $1.60^{\mathrm{a}}$ & $0.1005^{\mathrm{a}}$ & $0.518^{\mathrm{b}}$ & $0.281^{\mathrm{a}}$ & $0.163^{\mathrm{a}}$ \\
\hline HSEF & $48.3^{\mathrm{b}}$ & $1.56^{\mathrm{a}}$ & $0.0906^{\mathrm{a}}$ & $0.594^{\mathrm{ab}}$ & $0.311^{\mathrm{a}}$ & $0.151^{\mathrm{a}}$ \\
\hline Lienhauchi & $48.9^{\mathrm{ab}}$ & $1.96^{\mathrm{a}}$ & $0.1079^{\mathrm{a}}$ & $0.748^{\mathrm{a}}$ & $0.323^{\mathrm{a}}$ & $0.166^{\mathrm{a}}$ \\
\hline \multicolumn{7}{|l|}{ Other } \\
\hline Mt Peitungyen & $49.1^{\mathrm{a}}$ & $2.32^{\mathrm{a}}$ & $0.1310^{\mathrm{a}}$ & $0.400^{\mathrm{ab}}$ & $0.586^{\mathrm{a}}$ & $0.178^{\mathrm{a}}$ \\
\hline HSEF & $49.0^{\mathrm{a}}$ & $2.37^{\mathrm{a}}$ & $0.1231^{\mathrm{a}}$ & $0.344^{\mathrm{b}}$ & $0.593^{\mathrm{a}}$ & $0.148^{\mathrm{a}}$ \\
\hline Lienhauchi & $47.7^{\mathrm{a}}$ & $2.23^{\mathrm{a}}$ & $0.1108^{\mathrm{a}}$ & $0.475^{\mathrm{a}}$ & $0.524^{\mathrm{a}}$ & $0.161^{\mathrm{a}}$ \\
\hline
\end{tabular}


Table 5 The element fluxes $\left(\mathrm{kg} \mathrm{ha}^{-1}\right.$ year $\left.^{-1}\right)$ and the contribution (\%) of evergreen hardwood litterfall (leaf, twigs, reproduction, and other material) among different elevation in central Taiwan during May, 2009 to February, 2010

\begin{tabular}{|c|c|c|c|c|c|c|c|c|c|c|c|c|}
\hline \multirow[t]{2}{*}{ Parameter } & \multicolumn{2}{|l|}{$\mathrm{C}$} & \multicolumn{2}{|l|}{$\mathrm{N}$} & \multicolumn{2}{|l|}{$\mathrm{P}$} & \multicolumn{2}{|l|}{$\mathrm{K}$} & \multicolumn{2}{|l|}{$\mathrm{Ca}$} & \multicolumn{2}{|l|}{$\mathrm{Mg}$} \\
\hline & $\begin{array}{l}\mathrm{kg} \mathrm{ha}^{-1} \\
\text { year }^{-1}\end{array}$ & $\%$ & $\begin{array}{l}\mathrm{kg} \mathrm{ha}^{-1} \\
\text { year }^{-1}\end{array}$ & $\%$ & $\begin{array}{l}\mathrm{kg} \mathrm{ha}^{-1} \\
\text { year }^{-1}\end{array}$ & $\%$ & $\begin{array}{l}\mathrm{kg} \mathrm{ha}^{-1} \\
\text { year }^{-1}\end{array}$ & $\%$ & $\begin{array}{l}\mathrm{kg} \mathrm{ha}^{-1} \\
\text { year }^{-1}\end{array}$ & $\%$ & $\begin{array}{l}\mathrm{kg} \mathrm{ha}^{-1} \\
\text { year }^{-1}\end{array}$ & $\%$ \\
\hline \multicolumn{13}{|l|}{ Mt Peitungyen } \\
\hline Leaves & 2039 & 62 & $58.22^{\mathrm{b}}$ & 59 & 1.936 & 48 & $15.01^{\mathrm{b}}$ & 64 & 21.80 & 59 & 7.174 & 61 \\
\hline Twigs & 579 & 18 & $13.97^{\mathrm{j}}$ & 14 & 0.499 & 12 & $1.98^{\mathrm{j}}$ & 8 & 9.62 & 26 & 1.986 & 17 \\
\hline Reproduction & 519 & 16 & 17.59 & 18 & 1.098 & 27 & $5.21^{0}$ & 22 & 3.15 & 9 & 1.837 & 16 \\
\hline Other & 172 & 5 & 8.47 & 9 & 0.472 & 12 & $1.39^{0}$ & 6 & 2.10 & 6 & 0.671 & 6 \\
\hline Total & 3308 & & $98.3^{\mathrm{y}}$ & & 4.00 & & $23.6^{\mathrm{y}}$ & & 36.7 & & 11.7 & \\
\hline \multicolumn{13}{|l|}{ HSEF } \\
\hline Leaves & 2671 & 66 & $73.77^{\mathrm{ab}}$ & 64 & 1.962 & 48 & $16.81^{\mathrm{b}}$ & 64 & 27.18 & 66 & 8.636 & 66 \\
\hline Twigs & 741 & 18 & $16.13^{\mathrm{j}}$ & 14 & 0.455 & 11 & $2.52^{\mathrm{j}}$ & 10 & 8.76 & 21 & 2.291 & 18 \\
\hline Reproduction & 386 & 10 & 12.19 & 11 & 0.879 & 22 & $4.89^{0}$ & 19 & 2.40 & 6 & 1.181 & 9 \\
\hline Other & 261 & 6 & 12.48 & 11 & 0.755 & 19 & $2.02^{0}$ & 8 & 2.99 & 7 & 0.852 & 7 \\
\hline Total & 4059 & & $114.6^{\mathrm{xy}}$ & & 4.05 & & $26.2^{\mathrm{y}}$ & & 41.3 & & 13.0 & \\
\hline \multicolumn{13}{|l|}{ Luenhauchi } \\
\hline Leaves & 3096 & 68 & $102.92^{\mathrm{a}}$ & 66 & 3.019 & 68 & $28.36^{\mathrm{a}}$ & 72 & 27.23 & 63 & 9.401 & 67 \\
\hline Twigs & 993 & 22 & $31.83^{\mathrm{i}}$ & 20 & 0.399 & 9 & $5.35^{\mathrm{i}}$ & 14 & 11.70 & 27 & 3.004 & 21 \\
\hline Reproduction & 264 & 6 & 10.57 & 7 & 0.541 & 12 & $3.66^{0}$ & 9 & 1.63 & 4 & 0.817 & 6 \\
\hline Other & 232 & 5 & 10.81 & 7 & 0.491 & 11 & $2.14^{0}$ & 5 & 2.45 & 6 & 0.772 & 6 \\
\hline Total & 4585 & & $156.1^{\mathrm{x}}$ & & 4.45 & & $39.5^{\mathrm{x}}$ & & 43.0 & & 14.0 & \\
\hline
\end{tabular}

Significant differences between components among elevations $(p<0.05)$ were indicated by letters

forest (5.6-15.3 $\mathrm{Mg} \mathrm{ha}^{-1}$ year $^{-1}$ ) (Vogt et al. 1986). In general, three factors would change with the elevation gradient, including the heat budget, water budget and plant growth form; and these factors might influence the primary production and litterfall (Reiners and Lang 1987). This study showed the litterfall tending to decrease with increased elevation, the same as in other forests. For example, the litterfall production in three tropical montane forests $(1,892,2,380$ and 3,060 m) in southern Ecuador (Röderstein et al. 2005) and at the ultrabasic rock site at Mt. Kinabalu (700-3,100 m) in Malaysia (Kitayama and Aiba 2002) decreased with increased elevation. The litterfall production at the 200-m site was significantly higher than at the 800-m site in the evergreen lowland rain forest on Bukit Belalong in Brunei (Pendry and Proctor 1996). However, when Röderstein et al. (2005) used a metaanalysis of the foliar litterfall data from many tropical forests

Table 6 The standing crop $\left(\mathrm{Mg} \mathrm{ha}^{-1}\right)$, element concentration (\%), and content $\left(\mathrm{kg} \mathrm{ha}^{-1}\right)$ in litter layer among different elevations in central Taiwan during May, 2009 to February, 2010

\begin{tabular}{|c|c|c|c|c|c|c|}
\hline \multirow[t]{2}{*}{ Element } & \multicolumn{2}{|l|}{ Mt Peitungyen } & \multicolumn{2}{|l|}{ HSEF } & \multicolumn{2}{|l|}{ Lienhauchi } \\
\hline & $\begin{array}{l}\text { Concentration } \\
(\%)\end{array}$ & $\begin{array}{l}\text { Content } \\
\left(\mathrm{kg} \mathrm{ha}^{-1}\right)\end{array}$ & $\begin{array}{l}\text { Concentration } \\
(\%)\end{array}$ & $\begin{array}{l}\text { Content } \\
\left(\mathrm{kg} \mathrm{ha}^{-1}\right)\end{array}$ & $\begin{array}{l}\text { Concentration } \\
(\%)\end{array}$ & $\begin{array}{l}\text { Content } \\
\left(\mathrm{kg} \mathrm{ha}^{-1}\right)\end{array}$ \\
\hline $\mathrm{C}$ & $49.1^{\mathrm{a}}$ & $6662^{x}$ & $47.0^{\mathrm{a}}$ & $4,924^{x}$ & $40.3^{\mathrm{b}}$ & $4623^{x}$ \\
\hline $\mathrm{N}$ & $1.63^{\mathrm{a}}$ & $217^{\mathrm{x}}$ & $1.53^{\mathrm{a}}$ & $159^{x}$ & $1.59^{\mathrm{a}}$ & $189^{\mathrm{x}}$ \\
\hline$P$ & $0.0637^{\mathrm{a}}$ & $8.62^{\mathrm{x}}$ & $0.0503^{\mathrm{b}}$ & $4.85^{\mathrm{y}}$ & $0.0473^{\mathrm{b}}$ & $6.11^{\mathrm{xy}}$ \\
\hline K & $0.193^{\mathrm{b}}$ & $25.6^{\mathrm{y}}$ & $0.158^{\mathrm{b}}$ & $18.4^{\mathrm{y}}$ & $0.565^{\mathrm{a}}$ & $75.2^{\mathrm{x}}$ \\
\hline $\mathrm{Ca}$ & $0.676^{\mathrm{a}}$ & $91.2^{\mathrm{x}}$ & $0.761^{\mathrm{a}}$ & $85.3^{\mathrm{x}}$ & $0.594^{\mathrm{a}}$ & $71.2^{\mathrm{x}}$ \\
\hline $\mathrm{Mg}$ & $0.1385^{\mathrm{a}}$ & $18.3^{\mathrm{x}}$ & $0.1163^{\mathrm{ab}}$ & $12.1^{\mathrm{xy}}$ & $0.0936^{\mathrm{b}}$ & $10.4^{\mathrm{y}}$ \\
\hline $\mathrm{C} / \mathrm{N}$ & $30.9^{\mathrm{A}}$ & & $31.6^{\mathrm{A}}$ & & $25.6^{\mathrm{B}}$ & \\
\hline $\begin{array}{l}\text { Standing crop } \\
\left(\mathrm{Mg} \mathrm{ha}^{-1}\right)\end{array}$ & $13.5 \pm 7.2$ & & $10.6 \pm 4.8$ & & $12.0 \pm 4.4$ & \\
\hline
\end{tabular}


(1,000-3,060 m), they did not find a significant change with elevation, and Kitayama and Aiba (2002) also did not find the litterfall to decrease with elevation $(700-3,100 \mathrm{~m})$ in the sedimentary rock site at Mt. Kinabalu.

Elevation was a synthetically created environmental factor that included temperature and rainfall, which adequately determined the annual litterfall production (Brown and Lugo 1982). Substituting the annual mean temperature and rainfall data at each site in the Brown and Lugo (1982) formula,

$$
\begin{aligned}
& \mathrm{Y}=16.0+16.7 \log \mathrm{X}-6.5 \mathrm{X}, \\
& \mathrm{X}=\mathrm{T} / \mathrm{P} \times 100\left(\mathrm{Y}, \mathrm{Mg} \mathrm{ha}^{-1} \text { year }^{-1} ; \mathrm{T},{ }^{\circ} \mathrm{C} ; \mathrm{P}, \mathrm{mm} \text { year }^{-1}\right),
\end{aligned}
$$

we obtained estimated values of 7.17,8.59, and $9.46 \mathrm{Mg} \mathrm{ha}^{-1}$ year $^{-1}$ at Mt. Peitungyen, HSEF and Lienhauchi, respectively, which slightly overestimated the monitoring data.

According to Table 3, both rainfall and temperature had a positive relation with the litterfall production at Mt. Peitungyen, indicating that litterfall production is controlled by the two factors. However, the litterfall production was controlled by temperature at HSEF and by rainfall at Lienhauchi. In general, the amount of the other material (including insect bodies and feces) was positively affected by temperature in the three evergreen hardwood forests, and this may be related to the actions of insects during the warm summer.

The good canopy under enriching light favored the woody plants and increased production of flowers and fruit. According to field observation at Mt. Peitungyen, there was more space (lower LAI) between the canopies, allowing the trees to get more light for photosynthesis, promoting flower development. This explains why the amount of reproductive litter was significantly higher at Mt. Peitungyen than at Lienhauchi.

\subsection{Litterfall nutrient return and accumulation}

The $\mathrm{N}$ concentration in the leaf litterfall at Lienhauchi was higher than at HSEF, indicating a contribution from nonpoint source pollution via agricultural and human activity. The ammonia concentration in the bark epiphyte and soil of Pinus sylvestris in the ecosystem near a nitrogen-manure factory was higher than in a pollution controlled area in Poland (Seniczak et al. 1998). The presence of M. macrocarpa, a nitrogen-fixation species, would also affect the results. Killingbeck and Whitford (2001) indicated that a symbiotic nitrogen-fixing species, e.g., Prosopis glandulosa, maintained at least 2.3 times more nitrogen concentration in the foliar litter than other species.

Liu et al. (2006), concerned with the effect of temperature or rainfall on the $\mathrm{N}$ concentration in leaf litter, performed regression analysis on an Eurasian functional group forest (including conifers, broadleafs, deciduous plants, evergreens, and the genus Pinus) and found that the combined temperature and precipitation accounted for $30-52 \%$ of the variation in the $\mathrm{N}$ concentration in leaf litter for all the groups. There were highly significant linear $(p<0.001)$ relations that did not consider the factors, such as species composition, $\mathrm{N}$ deposition in the atmosphere, elevation, slope, and soil $\mathrm{N}$ concentrations. Although rainfall was not the highest at Lienhauchi, the temperature was higher than the other two sites. This may explain the results for the higher leaf $\mathrm{N}$ concentration, but we need to collect more data to confirm these results. At Lienhauchi, the K concentration of the leaf litterfall was higher than at the other sites, which might relate to the contribution from nonpoint source pollution, higher temperatures, or soil conditions.

Nutrient retranslocation, a common phenomenon in woody plants, refers to the resorption of the movable nutrients from senesced organs to permanent tissue for storage and usage. Killingbeck (1996) investigated nutrient resorption proficiency, based on the mean concentration of $\mathrm{N}$ and $\mathrm{P}$ in the leaf litterfall. An $\mathrm{N}$ concentration lower than $0.7 \%$ represents complete resorption, but higher than $1.0 \%$ represents incomplete resorption, and a $\mathrm{P}$ concentration lower than $0.04 \%$ represents complete resorption, but higher than $0.05 \%$ represents incomplete resorption in senesced leaves in an evergreen species. We compared our results (Table 4) with the critical value and found that the three sites showed incomplete $\mathrm{N}$ resorption, but complete $\mathrm{P}$ resorption at HSEF. The result indicated that $\mathrm{P}$ was the limiting nutrient at HSEF.

The litterfall nutrient concentration may be affected by temperature (Liu et al. 2006). In general, temperature usually decreased with increasing elevation. In Europe, Oleksyn et al. (2003) indicated that in Pinus sylvestris populations at high elevations, decomposition was slower and the longer retention time in the nutrient-limited soil led to lower $\mathrm{N}$ and $\mathrm{P}$ concentrations in the senesced leaves and led to higher resorption proficiency. In our study, the $\mathrm{N}$ concentration in the leaf litterfall at Mt. Peitungyen (where the annual mean temperature was the lowest) was the lowest, and the resorption proficiency was the highest. The results matched those found by Oleksyn et al. (2003). They found that when the annual mean temperature was lower, the $\mathrm{N}$ concentration in the leaves was lower, but they did not find the same trend for $\mathrm{P}$ concentrations.

The concentrations of $\mathrm{N}$ in the leaf and twig litterfall at Mt. Peitungyen and at HSEF were lower than in the floor litter (Tables 4 and 6), which matched the results found in the lowland rain forest in Brunei and in the neotropical montane forest of Costa Rica (Nadkarni and Matelson 1992; Pendry and Proctor 1996), probably due to microbial immobilization in the forest floor litter. However, the 
concentrations of $\mathrm{N}$ in the leaf litterfall were higher than in the floor litter at Lienhauchi, and the $\mathrm{C} / \mathrm{N}$ ratio (30 in the litterfall and 25 in the litter) was lower on the litter floor. The $\mathrm{N}$ decomposition released the nutrient as a source for the ecosystem, and then it abundantly supplied $\mathrm{N}$ to the microbes sinking into the ecosystem. The annual mean temperature was higher $\left(20.3^{\circ} \mathrm{C}\right)$ at Lienhauchi than at the other two sites and likely resulted in strongly microbial activity, promoting mineralization of the litter. At the three elevations, the $\mathrm{K}$ and $\mathrm{Mg}$ concentrations in the floor litter were lower than in the leaf and twig portions of the litterfall, probably caused by mineral leaching (Kozlowski et al. 1991; Nadkarni and Matelson 1992).

4.3 Litter and decomposition rate along different elevation sites

The forest floor mass usually increases with a decrease in temperature and as the elevation increases toward the pole (Vogt et al. 1986). Horng et al. (2003) studied the accumulation of floor litter in Taiwan, and their results showed the litter floor amount ranged from 2.31 to $13.39 \mathrm{Mg} \mathrm{ha}^{-1}$ in evergreen hardwood forests at elevations of 400-2,300 m. Our results at Lienhauchi and HSEF were within that range, but were slightly higher at Mt. Peitungyen.

The carbon concentration in the forest floor litter increased as the elevation increased, similar to the results of Yen and Shiang (2007), who indicated that the carbon concentration of the forest floor litter at high elevation $(\geqq 2,500 \mathrm{~m})$ was significantly higher than at low elevation $(\leqq 1,499 \mathrm{~m})$. Because the temperature decreased with increased elevation, the decomposition process was slower at high elevations (Kitayama and Aiba 2002), and the carbon concentration was increased.

We estimated the decomposition rate of the forest floor by the methods proposed by Olson (1963). The results showed that the rate decreased as the elevation increased, indicating that the decomposition rate was slower at high elevation. In a warm climate, the rate of organic matter decomposition is faster, and the mineral nutrients accumulate in or on the soil; however, in a cold climate, the decomposition is slower, and the mineral nutrients accumulate in the litter, leading to a lack of mineral nutrients in the soil (Kozlowski et al. 1991). Similar cases occurred in other forests, such as the tropical rain forest at Mt. Kinabalu in Malaysia (Kitayama and Aiba 2002) and the evergreen lowland rain forest at Bukit Belalong in Brunei (Pendry and Proctor 1996). Simmons et al. (1996) indicated that the $\mathrm{C}$ turnover time was correlated to the latitude and temperature indices. Slower decomposition in the Northern region was attributed to a combination of lower specific activity at temperatures below $13^{\circ} \mathrm{C}$, cooler average temperatures, and a shorter frost-free season. Domisch et al. (2006) suggested that the temperature of the soil was an important factor influencing organic matter decomposition, and therefore, global warming may speed up the decomposition rate.

For microbes, $\mathrm{N}$ is an important nutrient, and $\mathrm{C}$ is a main source of energy, so the $\mathrm{C} / \mathrm{N}$ ratio is one of the factors that affect the decomposition rate. Although the $\mathrm{N}$ concentration in litter showed no significant difference among the elevations, the $\mathrm{C}$ concentration in litter at Mt. Peitungyen and HSEF were significantly higher than that at Lienhauchi. Consequently, the $\mathrm{C} / \mathrm{N}$ ratio in the litter showed a significant difference among the elevations and was lower at Lienhauchi than at the higher elevation forests. Vesterdal et al. (2008) studied the forest floor beneath six common European tree species and indicated a strong relation between the decomposition constant of the $\mathrm{C}$ and $\mathrm{N}$ in the forest floor leaf and the $\mathrm{C} / \mathrm{N}$ ratio in the leaf litterfall. The results showed that a higher $\mathrm{C} / \mathrm{N}$ ratio in the leaf litterfall resulted from a slower organic matter decomposition rate. In our study, at higher elevation sites (Mt. Peitungyen), the $\mathrm{C} / \mathrm{N}$ ratio in the litter was higher and the decomposition rate was slower than at the lower elevation site (Lienhauchi). However, Garten and Hanson (2006) indicated that the $\mathrm{N}$ concentration in the litter floor increased with elevation, and the $\mathrm{C} / \mathrm{N}$ ratio in the litter decreased as the elevation increased. Berg (2000) deemed that a higher $\mathrm{N}$ concentration or a lower $\mathrm{C} / \mathrm{N}$ ratio in the litterfall quality would lead to a great deal of organic matter remaining in the soil and a greater accumulation of humus at the end of the decomposition. He indicated that a high $\mathrm{N}$ concentration inhibits the lignin degradation enzyme that drives humification, thereby restricting the soil organic matter decomposition.

\section{Conclusions}

Based on monitoring litterfall along three elevations in central Taiwan, we conclude that the annual litterfall (9.17-6.58 $\mathrm{Mg} \mathrm{ha}^{-1}$ year $^{-1}$ ) and decomposition constant $(0.777-0.487)$ decreased with an increase in elevation. The nutrient fluxes increased as elevation decreased. Although the mass of the standing crop litter among the different elevations showed no significant differences, the $\mathrm{C}$ concentration was significantly higher at the highest elevation forest than at the lowest forest. At low elevation forests, the $\mathrm{C} / \mathrm{N}$ ratio in the litter was lower than that at higher elevation, and the decomposition rate was faster. Thus, the forest managers should pay more attention to understand and monitor plant community responses to global warming and nutrient loss.

Acknowledgements The authors thank the National Science Council, Taiwan, for financial support (NSC 97-2321-B-005-013). 


\section{References}

Aceñolaza PG, Zamboni LP, Rodriguez EE, Gallardo JF (2010) Litterfall production in forests located at the Pre-delta area of the Paraná River (Argentina). Ann For Sci 67:311

Berg B (2000) Litter decomposition and organic matter turnover in northern forest soils. For Ecol Manage 133:13-22

Berg B, Meentemeyer V (2001) Litter fall in some European coniferous forests as dependent on climate: a symthesis. Can J For Res 31:292-301

Brown SJ, Lugo AE (1982) The storage and production of organic matter in tropical forests and their role in global carbon cycle. Biotropica 14:161-187

Chiou CR, Chen TY, Liu HY, Wang JC, Yeh CL, Hsieh CF (2009) Atlas of natural vegetation in Taiwan. Forestry Bureau, Council of Agriculture, Executive Yuan (in Chinese)

Domisch T, Finér L, Laine J, Laiho R (2006) Decomposition and nitrogen dynamics of litter in peat soils from two climatic regions under different temperature regimes. Eur J Soil Biol 42:74-81

Facelli JM, Pickett STA (1991) Plant litter: its dynamics and effects on plant community structure. Bot Rev 57:1-32

Garten CT, Hanson PJ (2006) Measured forest soil C stocks and estimated turnover times along an elevation gradient. Geoderma 136:342-352

Horng FW, Huang CM, Lin KC, Du CT, Cheng LC (2003) Organic matter accumulation in forest floors of forest ecosystems in Taiwan. Taiwan J For Sci 18:101-106

Killingbeck KT (1996) Nutrients in senesced leaves: key to the search for potential resorption and resorption proficiency. Ecology $77: 1716-1727$

Killingbeck KT, Whitford WG (2001) Nutrient resorption in shrubs growing by design, and by default in Chihuahuan Desert arroyos. Oecologia 128:351-359

Kitayama K, Aiba S (2002) Ecosystem structure and productivity of tropical rain forests along altitudinal gradients with contrasting soil phosphorus pools on Mount Kinabalu, Borneo. J Ecol 90:37-51

Kozlowski TT, Kramer PJ, Pallardy SG (1991) The physiological ecology of woody plants. Academic, San Diego, p 657

Liu C, Westman CJ, Berg B, Kutsch W, Wang GZ, Man R, Ilvesniemi H (2004) Variation in litterfall-climate relationships between coniferous and broadleaf forests in Eurasia. Global Ecol Biogeogr $13: 105-114$
Liu C, Berg B, Kutsch W, Westman CJ, Ilvesniemi H, Shen X, Shen G (2006) Leaf litter nitrogen concentration as related to climatic factors in Eurasian forests. Global Ecol Biogeogr 15:438444

Nadkarni NM, Matelson TJ (1992) Biomass and nutrient dynamics of fine litter of terrestrially rooted material in a meotropical montane forest, Costa Rica. Biotropica 24:113-120

Oleksyn J, Reich PB, Zytkowiak R, Karolewski P, Tjoelker MG (2003) Nutrient conservation increases with latitude of origin in European Pinus sylvestris populations. Oecologia 136:220-235

Olson JS (1963) Energy storage and the blance of producers and decomposers in ecological systems. Ecology 44:322-331

Pendry CA, Proctor J (1996) The cause of altitudinal zonation of rain forests on Bukit Belalong, Brunei. J Ecol 84:407-418

Reiners WA, Lang GE (1987) Change in litterfall along a gradient in altitude. J Ecol 75:629-638

Röderstein M, Hertel D, Leuschner C (2005) Above- and belowground litter production in three tropical montane forests in southern Ecuador. J Trop Ecol 21:483-492

Seniczak S, Dabrowski J, Klimek A, Kaczmarek S (1998) Effects of air pollution produced by a nitrogen fertilizer factory on the mites (Acari) associated with young Scots pine forests in Poland. Appl Soil Ecol 9:453-458

Simmons JA, Fernandez IJ, Briggs RD, Delaney MT (1996) Forest floor carbon pools and fluxes along a regional climate gradient in Maine, USA. For Ecol Manage 84:81-95

Staelens J, Nachtergale L, De Schrijver A, Vanhellemont M, Wuyts K, Verheyen K (2011) Spatio-temporal litterfall dynamics in a 60-year-old mixed deciduous forest. Ann For Sci 68:89-98

Tripathi SK, Sumida A, Shibata H, Ono K, Uemura S, Kodama Y, Hara $\mathrm{T}$ (2006) Leaf litterfall and decomposition of different above- and belowground parts of birch (Betula ermanii) trees and dwarf bamboo (Sasa kurilensis) shrubs in a young secondary forest in Northern Japan. Biol Fertil Soils 43:237-246

Vesterdal L, Schmidt IK, Callesen I, Nilsson LO, Gundersen P (2008) Carbon and nitrogen in forest floor and mineral soil under six common European tree species. For Ecol Manage 255:35-48

Vogt KA, Grier CC, Vogt DJ (1986) Production, turnover, and nutrient dynamics of above- and belowground detritus of world forests. Adv Ecol Res 15:303-377

Yen CH, Shiang YJ (2007) Using forest site patches to estimate the soil organic carbon pool in the Puli and Luanda forest working circles. Taiwan J For Sci 22:469-482 [in Chinese with English summary] 